\title{
The Place of African Traditional Religion in the Democratic Republic of the Congo since the Advent of Christianity
}

\author{
Mbangu Anicet Muyingi (PhD) \\ Department of Philosophy and Theology, School of Basic Sciences \\ North-West University, Vaal Triangle Campus \\ Email: anicetmbangu@gmail.com
}

\author{
Doi:10.5901/mjss.2014.v5n14p539
}

\begin{abstract}
This article seeks to investigate the social status attributed to African Traditional Religion (ATR) in inter-religious encounters with Christianity, since its advent, in the Democratic Republic of the Congo (DRC). The findings show that ATR in the DRC is marginalised because of, inter alia: the prejudices that followers inherited from their forebears; ATR lacks the hallmarks of a true religion; it is viewed as primitive as well as politically and economically weak without future; and the fear that the accommodation of ATR will result in syncretism and nominalism.
\end{abstract}

Keywords: Place, African Traditional Religion, the Democratic Republic of the Congo, Advent, Christianity

\section{Introduction}

This article explores the place of African Traditional Religion (specifically Congolese Traditional Religion) in inter-religious encounters with Christianity in the Democratic Republic of the Congo (DRC). The primal religion of the indigenes of the DRC is Congolese Traditional Religions (CTRs) (Mbiti, 1990: 11). Congolese Traditional Religions are transferred as it is a custom in Africa from one generation to another by word of mouth (Mulago, 1991: 2). In other words, Congolese Traditional Religions are part of the Congolese heritage (beliefs; practices; ceremonies and festivals; religious objects and places; values and morals; religious officials or leaders). Such transfer is relevant to the Congolese people today because Congolese need to know their history and development of their country.

The African indigenous peoples accommodated the immigration of Westerners of different religious backgrounds who came to change their lives (Alie, 1990: 101-111). The DRC's indigenous population were not accepting of Western missionaries who changed their social values, lives and religions. The Congolese Traditionalists first encountered Christianity in the fifteenth century (Vansina, 2010: 93). When Christians arrived, they (Christianity) were confronted with Congolese Traditional Religious forces. Vansina (2010: 93) further argues that this was the beginning of a long history of coexistence among the two religions (followers of ATR, and Christianity) in the DRC. For the most part, this relationship has been cordial. However, this peaceful coexistence does not imply equality.

As in same experiences of encounters and coexistence in Africa, there have been challenges as well as benefits. People living side-by-side meet and interact personally and communally on a regular basis (Bae, 2007: 25). They share common resources and communal benefits. The social and cultural interaction and cooperation involved in their dialogue of life are what compel Congolese to understand the worldviews of Western missionaries and to seek out better relationships with them. Hasting (2007: 60) argues that the early Christian missionary activity in the DRC was both ethnocentric and iconoclastic in its attitudes towards the Congolese culture and traditional religions. As a result of the Western missionaries' attitude towards the Congolese Traditional Religions, which have played and continue to play a vital role in the assimilation of Christianity, has come to be marginalised and stereotyped.

Despite the fact that Congolese Traditional Religions are marginalised, the estimated religious statistics in the country are as follows: Christians 70\%, Traditionalist 27\%, and Muslim 3\% (Maxwell, 2011: 23-33). Each of these religions constitutes an important phenomenon and affects Congolese life and the future of the nation. In that respect, this article supports also the proposal of a programme that should be developed for the re-constructive engagement of Traditionalists, and Christians in the emerging post-conflict of the DRC. Consequently, a call should be made requesting the assistance or participation of Congolese Traditional Religious leaders to facilitate the negotiation or reconciliation that is taking place in the country about the conflict that is ravaging the country at the moment. A possible approach to this religious negotiation or reconciliation may involve traditional values and methods to inform conflict resolution. Therefore, 
neglecting or relegating ATR, and by default CTRs, in the DRC to an inferior position will always cost the Congolese an essential component in the indigenous religious heritage, which constitutes a vital factor in the religious motivation and perception of Africans (Sanneh 2001: 86). In the Spirit of justice, relations among these two religious parties demand serious study and action.

In view of the long history of the two religions' (ATR and Christianity) coexistence and the important role that ATR and its followers can play in transforming the society and culture, this article aims to answer the following questions:

- Why do Christian leaders continue to marginalise ATR, its practices and followers from interfaith and governmental dialogue in the DRC?

- What is lacking in the Congolese Traditional Religions that continues to prevent followers of Christianity and the government from officially involving Traditionalists in the socio-political and religious development of the country?

In order to answer these questions, the place of Congolese Traditional Religions and its encounter with Christianity will be discussed according to existing literature. In addition, a review is offered concerning the different levels of interreligious dialogue and its obstacles. More importantly, the conditions for having a genuine and successful dialogue between ATR and Christianity will be discussed.

\section{Objectives}

The main objective of this article is to further awareness concerning the exclusion of traditional religiosity of the people of the DRC in the context of interfaith dialogue with Christianity. As such, the specific objective is to show the relevance and place of African Traditional Religion in inter-religious encounters.

\section{Research Methodology}

There is currently no consensus pertaining to the most acceptable methodology for the study of ATR. Ikenga-Metuh (1987:1-12), gives several reasons for the different approaches scholars have taken in the study of ATR. After studying the religious beliefs of several African societies, Ikenga-Metuh (1987:10), discussed and assessed the approaches he observed in his own research for which he adopted a Comparative Thematic Approach.

Westerlund (1993:15-24), a Scandinavian scholar who has shown tremendous interest in the study of ATR methodology, compares the different theories and methods that characterise the works of religionists and of anthropologists. Westerlund seems to prefer a phenomenological approach because it enables scholars to remain unbiased and allow the religion under study to speak for itself. Furthermore, Westerlund (1993:43-66) notes that scholars using the phenomenological and comparative approach have unintentionally Christianised African religions. To avoid a tendency to 'Westernise' African religions,' he recommended a limitative approach in the comparative study of African religions (Westerlund, 1993:59).

In consideration of the preceding methodological suggestion, this article will use one methodological approach which is the external desk research methodology (use of internet) to discuss the issue of ATR in inter-religious encounters in the DRC since the advent of Christianity. The external desk research methodology will be used to study the African Traditional Religion, its encounter with Christianity, and its fundamental tenets. Historical approach is employed to study the history of the contemporary inter-religious encounters, the dialogue, and the reasons for ATR's marginalisation. Historical approach will also be used to discuss the social status or place attributed to ATR in socio-political and interfaith dialogue in the DRC.

The rationale behind this choice of historical approach is that its focus has the ability to integrate and explore the general history of the beginnings of Christianity's encounter with ATR in the DRC and the holistic history of ATR in terms of its beliefs and practices relating to its geographical origins in the DRC. In order to provide answers to the questions posed in the introduction, and to discover the place of ATR in inter-religious dialogue in the DRC; the external desk research methodology is used. This methodological approach entails online desk research (use of the internet) data from funding agencies, published government data, books and articles.

\section{Significance of the Study}

The problem of the marginalization of ATR has attracted attention among researchers, academics, missionaries, development agencies and communities. Research into the field of ATR requires urgent attention since it has important policy implications. The findings would benefit a number of stakeholders such as African governments, religious 
missionaries in Africa generally and in the DRC in particular, non-governmental organizations (NGOs), communities, indigenous clerics and religious leaders.

\section{Research on African Traditional Religion (ATR)}

Over the centuries there have been attempts to define the phenomenon of religion. These attempts have come from various perspectives, ranging from psychological, sociological and anthropological perspectives to the philosophical and theological perspectives (Momen 1999:52-73) and most recently, definitions from a biological perspective have materialised (Hammer 2005: 10). Not only can these attempts at defining the phenomenon of religion be arranged according to perspectives, but also according to theories (Crosby 1981:5) that categorise definitions. Although varied, the theories and definitions became fixed in stereotypical forms. As a result of the confusion caused by the plethora of definitions there have even been suggestions to discard the mostly dominant Western term 'religion' altogether (Asad, cited in Figl 2003:71). For that reason Western scholars, in an attempt to understand African religion and its place in the world, have abstracted it from its cultural and historical contexts (Maluleka, 2001:59).

Scholars of religion like anthropologists, sociologists and philosophers 'Westernize African religions' (Westerlund 1993:59). Magesa (2002: 14) points out that Western scholars defined African religion in terms of Western philosophy. Magesa (2002:14-15) further notes that 'Western scholars define African religion in terms of animism, magic or fetishism, a multiplicity of ritual actions with natural objects as deities'. The purpose of Western scholars to define ATR in that way was 'to remove it from its origin and to do away with' (Westerlund, 1993: 60) this religion based on superstition and convert Africans to the God known by them (Western).

Indeed, the difficulty in defining ATR seems to come from the fact that its propagation is carried out by living it other than by preaching it (Denis, 2006:312). Denis (2006: 312) stipulates that the followers of ATR are more preoccupied with the practice of ATR than with the theory describing and explaining ATR. In ATR, dogmas and doctrines play a small role in the lives of its followers (Denis, 2006, 314). The definition of ATR becomes even more difficult because of its integral or holistic character. According to Mbiti (1990: 1) there is no separation between the religious (sacred) and the profane. ATR's influence covers all aspects of life, from before the birth of a person to long after s/he has died. It is a way of life and life is at its centre. It is concerned with life and how to protect it and augment it. Hence the remark, 'For the African, religion is literally life and life is religion' (Mbiti, 1997: 1-2).

According to Paul, (2004: 2) ATR is the indigenous religion of the Africans which was handed over from one generation to another by word of mouth until recent attempts at documentation. In other words, ATR is part of the African heritage (beliefs, practices, ceremonies and festivals, religious objects and places, values and morals, religious officials or leaders) (Mbiti, 1997: 11-13). ATR can thus be defined as the aboriginal religion of Africans, embraced by the forefathers of the present generations. It is described as the religion that emerged from the sustaining faith of the forebears of the present generation of Africans passed from generation to generations and is still practiced today by the present generation of Africans (Awolalu 1991:111). It is the religion without a founder as 'the founders cannot be found no matter how far we go back to history' (Awolalu 1991:111). ATR is the belief of the forefathers concerning the existence of the Supreme Being, divinities, Spirit beings, Ancestors and mysterious powers, good and evil and the afterlife. These are the essential characteristics of ATR (Thorpe, 1996: 9) which should be acknowledged and placed as a mother religion in the world.

The concept of ATR is very exciting and fascinating, but sadly uncared for and very much unrecognised even by the Africans themselves, who, very often out of ignorance, misinformation or naivety have not bothered to know its worth or importance. Momen (2009: 356) argues that ATR is part of the category designated as primal religion. Thorpe (1996: 5) states that a major characteristic of primal religions is the fact that they originated and developed in relative isolation from other cultures. Thorpe (1996:5) further characterises primal religion as a religion found among societies consisting of relatively small groups of individuals who are heavily dependent on one another, as such, Bernhard (cited in Figl 2003:260) and Sunder Meier (1999:31) talk about 'tribal societies'.

As this research does not intend to discuss primal religions but instead the place of ATR and its encounter with Christianity in the DRC, it is important to note that ATR must be understood as belonging to the Africans. It does not make ATR unique, but it does make Africans aware that different cultural-religious groups understand religion differently.

\section{Inter-religious Encounters in the DRC}

Very little or nothing has been written on interreligious encounters and dialogue between ATR and Christianity in the DRC. 
Ever since Christianity began its proselytizing activities in the DRC in the fifteenth century, it has encountered the various Traditional Religions of the country. These encounters have been negative. It is necessary to note that not all persons have the same attitude towards the ATR in the country. The fact is that some people, Christian missionaries in particular, have such a denigrating attitude to ATR that they see ATR, even in this twentieth first century, as the animistic religions of primitive people (Pollitt, 1996:25). The Christian attitude towards ATR in the DRC is predominately negative. As a result, ATR and indeed other indigenous people, neither features in international inter-faith dialogue nor in political dialogue.

Blyden (1994: 14) expresses that the attitude of Christian missionaries towards African culture and religion is less than tolerant and is derogatory. He further states that the teachings of Christianity in the DRC are exclusive and uncompromising. This is because there was no acceptance of the existence of anything called Congolese believe by missionaries, travellers, anthropologists and historians in the DRC during earlier times (Doherty, 2008:1). Additionally, Congolese Traditional Religion and culture was also disregarded, condemning what they thought never existed. Consequently, the one without history cannot have religion (Denis 2006:312).

To some anthropologists, 'untutored' Africans cannot know God as the idea of God is philosophical. To the missionaries in the early days, Africans were not fully human; they prohibited polygamy, initiation rites, ancestral belief and other indigenous practices (Doherty, 2008, 2005: 19). During the period of Colonisation, ATR was widely practised, although in secret. The reason for the secret practice was that the missionaries, by the 19th century, 'whether they were Congregational, Methodist, Anglican and Lutheran or, Catholic, were aggressively opposed to traditional African practices in the DRC that they considered barbaric and based on superstition' (Denis 2006:310-323).

In other words, Christianity from its earliest history has maintained a negative attitude toward ATR in the country. As early as the period of Cyprian of Carthage (258), it was held that there was no salvation outside the Christian church (Gort 2008:748). He wrote that 'he cannot have God for his Father who does not have the church for his mother' (cited by Gort 2008:748). That is why the Congolese Traditional Religions are viewed as 'non-Christian'. They are perceived as expressions of 'heathen unbelief and evil superstition' and they are perceived as a world outside the church which is seen as the 'kingdom of darkness' (Gort 2008:748).

Although for the next 1500 years or more, what Christians thought of other religious traditions were governed by the above perception, there existed those few who challenged the prevailing thought and advocated a more accommodating model of encounter with other religions. Pope Gregory the Great (c. 540-604), Raymond Lull (c. 12351315), Bartholomew de las Casas (1474-1566), Matteo Ricci (1552-1610) and Robert de Nobili (1577-1656) were some of the few who preached accommodation (Gort 2008:749). Unfortunately, such protests went unabated, even presently, and the missionary attitudes are still guided by 'unbridled feelings of superiority' confirming the notion why ATR in the $\mathrm{DRC}$ is still marginalised.

\section{Dialogue and Cooperation between Christianity and ATR in the DRC}

According to Adamo (1989: 82-88), dialogue is a conversation between two people or an exchange of ideas and opinions. Panikkar (1975: 407-409) states that religious dialogue means the exchange of views and insights by means of concepts expressed in words that are based on previous agreement concerning the common, which the dialogue thereafter tries to widen and deepen, so as to pinpoint divergences, similarities, complementarities, and criticisms, as well as to find the loci where mutual influence or fecundation may take place. In ecumenical context, dialogue is more than a conversation or exchange of ideas or opinion. It means the sharing of religious conviction for the purpose of mutual understanding that will eventually result in 'a peaceful coexistence amongst the world community of various religious faith' (Adamo 2006:8288).

Indeed, there are different levels of dialogue. According to Gort (2008:758-760) the first level of inter-religious dialogue is what may be called 'the dialogue of histories' which is an important consideration for this article. This type of dialogue begins with a serious analysis of the past relations between the religions involved in order to know what stance and respect they have for one another. The position they occupy vis-à-vis each other on the political, social and economic planes so that at this level questions of justice, injustice, power, domination, wealth and poverty is discussed and ironed out. In the DRC, this kind or type of dialogue has never happen for the simple reason that ATR of the Congolese appears to be a morass of bizarre beliefs and practice (Vansina, 2010: 73). Congolese Traditional Religions are qualifying as a primitive religion, as merely the first stage of the evolution of human religious history, inherited from their forebears. This attitude of qualifying Congolese Traditional Religions is evident when brothers embrace different religions and discrimination among them is open. In a historical context, such attitudes are all too easily understandable because according to Christian religion, Congolese Traditional Religions remain mystical with elements of magic, witchcraft, 
fetishism, and sorcery. All these mystical powers are used to do harm to the human being or property, not to build and to protect the community. All this terminology expresses not only the complexity of Christianity but also the awkwardness which its inventors felt when faced with such inferior forms of religion.

\section{Discussion and the Place of ATR in the DRC}

Philosophically, from the beginning of time, people all over the world have tried to explain the existence of God and sought to come closer to Him through divinities or spirits. This has been known through the encounter and dialogue between the different traditional religions around the world. Also, every religion has reflected upon an ideal state of being where humans live life to its fullest. These fundamental questions of encounter between African Traditional Religion and Christianity have to be examined carefully. That is why in the DRC a genuine dialogue between Christianity and Congolese Traditional Religions is very important. In the view of what has been said above, one can easily observe that in the DRC there has not been a genuine dialogue between Congolese Traditional Religions and Christianity. As a consequence of the lack of dialogue between the two religions, Congolese Traditional Religions are secondary to Christianity, because according to some Christians, there is no relationship between the two religions. This argument whereby there is no relationship between the two religions has presented obstacles for genuine dialogue between leaders of Christianity and Congolese Traditional Religions. The first obstacle is that there is hostility on the part of Christianity against Congolese Traditional Religions. This is as a result of prejudices developed by Belgian colonial missionaries and feelings of religious superiority over Congolese Traditional Religion. The second obstacle has to do with the ill-conceived notion of Congolese Traditional Religions, such as the tendency of many Christians to reduce it to certain esoteric aspects that are disconcerting, or to demonize it completely. The third obstacle is the level of poverty and conflict in the DRC which elevates the hindrance related to the development of a genuine dialogue and highlights the socio political and economic democracy that is needed in the country. Where there is no peace, genuine dialogue is impossible.

Implicit in the right to freedom of thought, conscience and religion granted to any one individually or in association with others is also the right to equality and non-discrimination enshrined in the constitution of the DRC and in the international agreements such as the Universal Declaration of Human Rights. Accordingly, everyone is equal in the exercise of his/her right to freedom of religion. Every religious group is equal and no one should be discriminated against (Maxwell, 2011: 23-33). This principle of equality and non-discrimination in the DRC is not respected. The practice reveals that Christianity is more privileged than Congolese Traditional Religions that are marginalized in every aspect of Congolese life. For example, only Christian leaders are regularly invited by the government to attend public meetings or to discuss matters that concern the country.

The arguments above show clearly that Congolese Traditional Religion are discriminated against and marginalized. Congolese Traditional Religions are relegated beyond Christianity. The reason for this Christian relegation is that Congolese Traditional Religions are varyingly identified by names such as 'empire of Satan, pagans, heathens, idolatrous, polytheist, barbarians, superstitious, fetishists, and primitive' (Vansina, 2010: 93-104). CTRs are also synonymous to misery and superstitions. Congolese traditional religions are qualified to have no future be it in the churches or in the country as a whole.

The point of the foregoing analysis is to show that the place of Congolese Traditional Religions have been exaggerated through the assimilation of Christianity and in some cases, philosophical scholarship.

According to the view discussed above, the article recommends that it is important for the two religions (Christianity and Congolese Traditional Religions) to find common ground. Despite the real differences and disparities between religions, there is a basic stratum of human commonality that can make it possible for Congolese Traditional Religions and Christianity to communicate with one another and to discover a point of contact (Gort, 2008: 756). Such commonality may include: common experiences, fears, questions and sorrows that Congolese share. The main source of common ground should be the belief in God as the Creator of the Heavens and the Earth and His attributes. The attributes of God assigned by both religions can be another point of departure: holiness, goodness, mercy, immutability and righteousness. That the Supreme Being is the Father of all that exists and that there is unity of life and participation can be a common ground to start a genuine dialogue.

Furthermore, the DRC is in need of creating a religious association which can bring the two religions together in order to foster a better relationship which can be used as an agent for democracy, peace, national reconciliation, and development and for that the right to freedom of religion should be enjoyed according to the law of the country and the right of other people's beliefs should be respected. The association should establish or promote within the two religions the spirit of mutual respect and love rather than the spirit of exclusion, discrimination and marginalisation.

The Congolese Government Leaders should also consider Traditional Religious Leaders in the same way or 
manner as they consider Christian Leaders. The association should promote the place of Congolese Traditional Religions and help Christians to understand Congolese Traditional Religions and reach out to them. In other words, Christianity in its calling should faithfully interpret the gospel of Christ in the Congolese Traditional Religions and endeavour to attain a deeper understanding of Congolese culture which will ultimately foster a fruitful Christianity-Congolese traditional religious dialogue.

\section{Conclusion}

This article has attempted to identify the place of African Traditional Religions in inter-religious encounters in the Democratic Republic of the Congo (DRC) since the advent of Christianity. The article has highlighted that ATR and its followers have long been marginalised in inter-religious dialogue in the DRC since the fifteenth century. The reason is that ATR in the DRC is not organised or institutionalised like Christianity; again ATR in the DRC has no founder or leader who may be credited with the title. ATR lacks scripture; it is primitive and economically weak; and raises fears of syncretism and nominalism. Christians think it is not right to mix elements of ATR into Christianity. Therefore, as Kruger (2009: 144) puts it, anything that would dilute or substantially alter the basic structures of Christianity is strongly combated. Because of these reasons, Christians hold strong reservations about ATR and do not support the idea of including it in the DRC's inter-religious dialogue. This segment has attempted to answer the two questions that were identified in the introduction.

The article argued that nothing has been done by Christians or the government to recognise or acknowledge the place, the contribution and the role of ATR in the DRC's politics and life. If the government of the DRC need genuine peace in the country, the government must allow dialogue and cooperation between Christians and Congolese Traditional Leaders to take place and eventually include ATR in interfaith dialogue and cooperation. Christians must tolerate and respect ATR as a genuine religion, and must educate themselves about ATR and about their own respective faiths.

\section{References}

Adamo, D.T., (2006). Africa and Africans in the New Testament. University of America Press: Lamhart, MD.

Adamo, D.T., (1989). Salvation According to Christianity and Buddhism. The Journal of Religious Studies. 17(2), 82-88.

Adrian. H. (2007). The Church and Mission in Modern Africa. London: Burns and Oates.

Alie, Joe A. D. (1990). A New History of Sierra Leone. London: Macmillan.

Awolalu, J. O. and Dopamu, P. A. (1979). West African Traditional Religion. University of Ibanda: Nigeria.

Awolalu, J.O., (1991). 'The encounter Between African Traditional Religion and other Religions in Nigeria'. in J.K. Olupona (ed.). African Traditional Religion in Contemporary Society. Paragon House: St. Paul, MN. pp. 30-40,

Bae, C.S., (2007). Ancestor worship and the challenges it poses to the Christian mission and ministry. PhD thesis. University of Pretoria: South Africa.

Blyden, Edward. (1994). Christianity, Islam and the Negro Race. London

Denis, P., (2006). The Rise of Traditional African Religion in Post-Apartheid South Africa: in Missionalia. 34(2/3). 310-323.

Doherty, M., (2008). The Congo Balolo Mission and the Indigenous Christian Community: The Agency of Locals' in Evangelists of Empire: Missionaries in Colonial History, ed. Amanda Barry, Joanna Cruickshank, Andrew Brown-May and Patricia Grimshaw. University of Melbourne scholarship Research Centre: Melbourne.

Figl, J. (ed.). (2003). Handbuch Religionswissenschaft: Religionen und ihre zentrale Themen [Handbook of religious studies: Religions and their central themes], Tyrolia-Verlag, Innsbruck.

Gort, J.D., (2008). The Search for Interreligious Convivance, ongoing challenge and charge: Verbum et Ecclesia 29(3), 744-763.

Hammer, D.H., (2005). The God gene: How faith is hardwired into our genes, Anchor Books: New York.

Ikenga, M. E,. (1987). God and Man in African Religion. London: Geoffrey Chapman.

Kruger, J.S., Lubbe, G.J.A \& Steyn, H.C., (2009). The human search for meaning: A multireligion introduction to the religions of humankind, Van Schaik Publishers: Pretoria.

Magesa, L., (2002). African religion: The moral traditions of abundant life, Orbis Books: Maryknoll.

Maluleke, T.S., (1998). 'African traditional religions in Christian mission and Christian scholarship: Re-opening a debate that never started', Religion and Theology 5(2), 121-137.

Maluleke, T.S., (2001). 'Identity and integrity in African theology: A critical analysis', Religion and Theology 8(1), 26-39.

Maxwell, D. (2011). Photography and the Religious Encounter: Ambiguity and Aesthetics in missionary representations of the Luba of South East Belgian Congo: Comparative studies in society and History: in The Journal of Religious History, 53/1. pp 23-33.

Mbiti, J.S., (1990). African religions and philosophy (2nd ed). Heinemann Educational Publishers: Oxford.

Mbiti, J.S. (1997). Dreams as a point of Theological Dialogue Between Christianity and African Religion. Missionalia 25 (no. 1): 511-22.

Momen, M., (1999). Understanding religion: A thematic approach, Oneworld Publications: Oxford.

Mulago, Vincent. (1991). African Traditional Religion and Christianity: in African Traditional Religions in Contemporary Society, edited by 
Jacob K. Olupona, St. Paul, Minnesota: Paragon House.

Paul. G. (2004). Ghana's New Christianity: Pentecostalism in a Globalising African Economy. London: Hurst.

Pollitt, H. J. (1996). The Inter-faith movement: in the New age enters the Church. Spartan Press.

Sanneh. L. (2001). A Resurgent Church in a Troubled Continent: Review Essay of Bengt Sundkler's History of the Church in Africa. International Bulletin 25 (no.3, July):113-15.

Sunder Meier, T., (1999), Was ist Religion? Religionswissenschaft in theologischen Kontext [What is religion? Religious studies in a theological context]. Chr Kaiser Gütersloher Verlagshaus: Gütersloh.

Thorpe, S.A., (1996). Primal religions worldwide: An introductory descriptive review. University of South Africa: Pretoria.

Vansina, J., (2010). Being Colonised. The Kuba Experience in Rural Congo, 1880-1960 (Africa and the Diaspora). University of Wisconsin: Mandison.

Westerlund, D. (1993). The Study of African religions in retrospect: From Westernization to Africanization: in Religious Plurality in Africa: Essays in Honour of John S. Mbiti, edited by Jacob K. Olupona \& Sulayman S. Nyang, Berlin; New York: Mouton De Gruyter. 